ISSN No. 0974-035X

An Indexed, Refereed \& Peer Reviewed Journal of Higher Education

Towards Excellence

UGC-HUMAN RESOURCE DEVELOPMENT CENTRE,

GUJARAT UNIVERSITY, AHMEDABAD, INDIA

\title{
THEORETICAL FRAMEWORK OF BANKING RULES AND REGULATION AND ITS IMPACT ON INDIAN BANKING SECTOR.
}

\section{Prof.(Dr.) Urvi Amin}

\begin{abstract}
:
In this paper researcher focus on development of banking rules and regulations. Economic theory indicates a direct relationship of economic growth and financial investment resources time to time is been studies over here. At world glance impact of Glass-stealgall act and need to replace Glass-Steagall act with The Gramm-Leach-Bliley Act (GLBA) is explained in detail. To explain this in detail researcher also studied transformation in banking sector, regulatory framework, security standard, competitiveness in financial sector, risk association in this sector and legal and regulatory criteria for the same. How legal transformation affect economy and changes provide boost to economic development to growth is been studies over here.
\end{abstract}

\section{Introduction :}

Lack of financial resources normally generates vicious circle of poverty to the developing nation. Vicious circle of poverty develops a new term 'Inclusive Growth'. When in economy enhancement of investment opportunity emerged capacity of investment and pool of resources become possible. Assiduousness of financial institutions has resulted in excess the new door for the improvement - financial services. Any economy development is based on the core financial system. In the financial system of the country, banking organization is considered as the backbone of the economy. Researcher focuses on the different development into financial sector with regards to banking and commerce 


\section{Research Objectives :}

This research paper have following objectives:

- To study impact of banking rules and regulation on economic development

- To analysis dimensions of banking sector reform and its impact on developing economyIndia.

\section{Literature review.}

Barth J., Brumbaugh R. and Wilcox J. suggested, "Gramm Leach Bliley Act (GLBA) narrowed law which economically suggested holding companies from acquiring commercial firms or engaging in new commercial activity."1

Tanoue represented, "Monetary Control Act (MCA) limitations were removed with Federal Reserve Banks (FRBs), so healthy and competitive environment was helpful to the financial sector for developing Banking Correspondents (BCs)". ${ }^{2}$

The website http://www.epaynetwork.com acknowledges, "This system provided a large scale business operation and set a stabilized system for all banking operations." 3

This would develop large scale Automated Clearing House (ACH) services for banking operations. The conference of state bank supervision suggests, "The law's privacy measures were not as strict as some in the industry had feared--but Congress left the door open for stricter requirements at the state level." 4

Kroszner and Rajan showed, "Partly because commercial banks dealt with older and larger firms, the securities that they underwrote performed better than those underwritten by investment banks". 5

\section{Dimensions of banking sector reforms}

Researcher focuses on the different development into financial sector with regards to banking and commerce.

\section{Transform legal rules and regulations into banking segment :}


To expand banking services, continuous reframe adopted in the National Banking Act (NBA). Banking subsidiary which called as 'op subs' engage in activities beyond those permitted bank. To expand and reframe National Banking Act (NBA) continues efforts adopted by Office of the Comptroller of the Currency (OCC). Office of the Comptroller of the Currency (OCC) was reinterpreted certain 'Incidental' powers' that it was granted under the National Banking Act (NBA) which permit privileged power to operating subsidiaries 'op subs' of national banks.

By the early 1980s, securities, insurance and other firms began acquiring banks and then stopped either commercial lending or accepting demand deposits, so that they no longer qualified as banks.

\section{Regulatory framework}

Federal Reserve determines that the activity does not pose a sustaincial risk to the safety or soundness of banks. Federal reserve does not serve as the prime bank regulator except $15 \%$ of banks that are state chartered fed member banks. Federal bank is an act as ignition to growth to mobile banking, e-commerce and e-finance. However by 1994, the Riegle Neal act had effectively ended the remaining barriers to need to have identical institution base economic perform different task all different manner in significant direction. Some sort of re mould role of banking sector try to attempt with the reason. Gramm Leach Bliley Act (GLBA) would still not allow broad banking companies which engaged in banking, securities and insurance activities.

\section{Security standard:}

Glass Steagall board in their board federal reserve member banks to investigate shares of stocks and limited buying and selling securities as agent and maintain underwriting and dealing in most of the securities. It is also implied that Federal Reserve member banks from being affiliated with any company that is engaged principally then it is considered as illegitimate. Any deal between Federal Reserve member bank and any company which primarily engaged in underwriting or dealing insecurities all such securities exempted into the Glass- Steagall restrictions. The term 'Engaged Capacity' and 'bank-eligible securities' not well defined into the act. Rest concern in this like banks receive major problem with the payment system and with the federal deposit insurance and access to the payment system with discount window of the federal reserve implementation. 


\section{Competitiveness in financial sector :}

Competition in financial sector naïve stage as compare to other service sector. Competition is always welcomed for better serve but vigorous rivalry not prudent. Theoretical and empirical research provides more insightful code of conduct as a prudential policy towards banks. This policy also affects on the economic growth. In terms of the factors driving competition in financial sector and the empirical measurement of competition. Recent global financial crises draw attention on financial crisis clearly confirms the need for many policies which need stability to improve financial market adequate functioning.

\section{Risk association to the financial sector.}

In financial sector derivatives movement and global economy recession smacks banking sector.

Commercial bank occupies center place in the financial sector which improved substantially. Higher degree of risk helpful for larger scale exposure to the banking sector. It is essential to calculate risk which would be resultant into systematic risk category. To explore unbanked market, it is essential to have local mediatory. Accordingly, credit risk is diversifiable. Most of financial organization will report concentration by identical report which would be satisfied norms of the financial institutions

\section{Financial up gradation at global level}

Adoptions of technology and mobile phones have changed the overall scenario of financial inclusion. These technological advancements have forced the financial bodies to upgrade themselves as per need of present era. In financial services Society For Worldwide Interbank Financial Telecommunication (SWIFT) protocol plays vital role since 1977. Tressel, Thierry, and Thierry Verdier suggested, "Standard rules and regulations development to have a regulatory formation and grip and uniformity in the financial sector". ${ }^{6}$

\section{Impact of reform on Indian banking sector.}

Indian banking segment adopted suitable changes as per time needed. In Indian economy 1991 is known as milestone year which open doors for development. 1991 was known as LPGliberalization- Privatization- Globalization year in the Indian economy. Due to Glass Steagall act 
world economy suffered a lot. Changes in to Indian economy which needed technological support and huge capital investment. With LPG and FDI doors for global economy opened in India. In the year 1999 with Gramm Leach Bliley Act (GLBA) support to banking sector provided and with this act all curtailed act, is been now act by banking sector. In Indian banking sector would provided all sorts financial services, investment services and advisory services.

- From 1970-90, major countries depend on Public sector Bank to serve remote regions which prove to be landmark contribution of Micro Finance Institutions (MFI's) in financial sector. Technological enhancement and Point of Sales (POS) change the overall picture of banking service.

- The quality of information can interact with the size and structure of the financial system to affect the degree of access to financial system to affect the degree of access to financial services to more opaque firms such as Small and Medium Enterprises (SMEs).

- With technological improvement and information pool that spur consolidation can be offset factors

- Reserve Bank of India (RBI) policy makers have begun to pay close attention of Financial Inclusion (FI) from 2005..

- During 11th five year4 planning (2007-12) this time, the enforcement to multiple policy and industry changed. Banks have been asked to voluntarily make available a 'No-Frills' account, and all printed bank material has to be made available in regional languages. Know Your Customer (KYC) procedures have been simplified for low income groups." 7

\section{Conclusion.}

Any sector faced changes with the time span. Indian banking sector also faces and come out of all obstacles. All machines connected with the parent banking and serve to the left out genre till the date. This technovation converted reel time to real time in Indian economy and give boost up support for development of developing nation. Any country that generates own financial power with the help of banking services, competition into the banking services provides qualitative services to people. Continuous changes into banking sector provide boost to Indian economy for development and also give changes to people at large for better service utilizes. 


\section{$\underline{\text { References: }}$}

${ }^{1}$ Barth J., Brumbaugh R. and Wilcox J. (2000) 'The Repeal of Glass-Steagall and the Advent of Broad Banking'

2 Tanoue, Donna. (1999) 'Financial Services Modernization Act of 1999'

${ }^{3} \mathrm{http}: / / \mathrm{www}$.epaynetwork.com/wells.html. accessed on 3/3/2016 at 2:23 pm

4 Conference of State Bank Supervisors (1999), 'The law's privacy measures were not as strict as some in the industry had feared--but Congress left the door open for stricter requirements at the state level.'

${ }^{5}$ Kroszner, Randall, and Ragu R., (1997. "Organization Structure and Credibility: Evidence from Commercial Bank Securities Activities before the Glass-Steagall Act." Journal of Monetary Economics 39 (3), pp. 475-516.

${ }^{6}$ Tressel, Thierry, and Thierry Verdier, (2007), 'Does Financial Globalization Discipline Politically Connected Firms?’ Working Paper, IMF, Washington, D.C.

7 Swain P. , Singh B. 'Financial Inclusion of Rural Markets: Understanding the Current Indian' IIM Culcutta Working Paper Series WPS No. 630/ October 2008 page 5-7

\section{Prof.(Dr.) Urvi Amin Assistant Professor SJPI-NICM \\ urviamin@ymail.com

contact no : 9824337976

